\title{
AGE, GENDER, AND KNOWLEDGE ON COMPLICATIONS OF DIABETES MELLITUS WITH OBEDIENCE IN CHRONIC DISEASE MANAGEMENT PROGRAMS
}

\author{
Tri Ratih Agustina, Naura Rifdah, Nurjannah Sriayu, Naila Zulbahrina \\ Faculty of Medicine, Universitas Wijaya Kusuma, Surabaya
}

\begin{abstract}
Background: Diabetes Mellitus (DM) is a chronic and dangerous infectious disease. Various efforts to reduce morbidity and mortality due to diabetes have been carried out, one of which is the Chronic Disease Management Program (PROLANIS). Meanwhile, in its implementation, many are irregular. This study aimed to examine the relationship between age, gender, and level of knowledge with the complications of DM with obedience in following the PROLANIS.

Subjects and Method: This was a cross sectional study conducted in the working area of the Gondang Community Health Center, Mojokerto Regency, East Java. Total of 42 DM patients were enrolled in this study using total sampling technique. The independent variables were age, gender, and level of knowledge. The dependent variable was obedience in following the PROLANIS. Data were collected using questionnaire and analyzed using Chi square test. Results: Factors associated with obedience in following PROLANIS were age (OR $=22.75$; $95 \% \mathrm{CI}=2.42$ to $213.73 ; \mathrm{p}=0.002)$, gender $(\mathrm{OR}=12.00 ; 95 \% \mathrm{CI}=2.46$ to $58.47 ; \mathrm{p}=0.001)$ and the level of knowledge about DM complications (OR $=7.00 ; 95 \% \mathrm{CI}=1.72$ to $28.55 ; \mathrm{p}=$ o.006).

Conclusion: Age, gender, and level of knowledge about complications due to DM are related to the DM patient's obedience in following the Chronic Disease Management Program (PROLANIS).
\end{abstract}

Keywords: Diabetes Mellitus, Chronic Disease Management Program, PROLANIS, obedience

\section{Correspondence:}

Tri Ratih Agustina. Wijaya Faculty of Medicine, Universitas Wijaya Kusuma, Surabaya. Jl. Dukuh Kupang XXV No.54 Surabaya, East Java, Indonesia. Email: wildrizky@gmail.com Mobile: 0811372336 